\title{
Are the Medical Journals Justified in Criticizing India's COVID-19 Management Policy?
}

\author{
Velayudhan Mohan Kumar ${ }^{1,2}$ Seithikurippu R. Pandi-Perumal ${ }^{3,4}$ \\ Devendra Kumar Gupta ${ }^{5}$ \\ ${ }^{1}$ Retired Professor and Head, Department of Physiology, All India \\ Institute of Medical Sciences, New Delhi, India \\ ${ }^{2}$ Sree Chitra Tirunal Institute for Medical Sciences and Technology, \\ Thiruvananthapuram, Kerala, India \\ 3 Somnogen Canada Inc., Toronto, Ontario, Canada \\ ${ }^{4}$ Saveetha Medical College and Hospitals, Saveetha Institute of \\ Medical and Technical Sciences, Saveetha University, Chennai, \\ Tamil Nadu, India \\ 5 Retired Professor and Head, Department of Pediatric Surgery, All \\ India Institute of Medical Sciences, New Delhi, India
}

Ann Natl Acad Med Sci (India) 2021;57:65-68.

People generally trust medical publications, and their perspectives are accepted as gospel truth, as opposed to general media reports, which are taken with a grain of salt. So, the leading medical journals that have emerged as "superpowers" during the coronavirus disease 2019 (COVID-19) epidemic, should ensure that their publications are not used with political intent. ${ }^{1}$ There are many magazines and newspapers in India that have written articles against the central government and its handling of the second wave of the COVID-19 pandemic. ${ }^{2}$ But an international medical journal reproduced these allegations in a "world report" titled "Experts criticize India's complacency over COVID-19." The author of this article, has been writing in this journal against the Indian government's handling of COVID-19, based on distorted facts and figures. ${ }^{4,5}$ Biased news reports related to the second wave of COVID-19 were regularly appearing in another international medical journal also. ${ }^{6-9}$ In a "World View" published in this journal, the author states that "Indian scientific academies continue their head-in-the-sand approach, making no statements on super-spreader events or data access." 10

India, which has one of the biggest drug manufacturing capacities, has been planning to produce enough COVID-19 vaccines not only for its people but also to export

Address for correspondence Devendra K. Gupta, Honorary Secretary, National Academy of Medical Sciences (India), Ring Road, Ansari Nagar, New Delhi 110029, India (e-mail: profdkgupta@gmail.com).
DOI https://doi.org/ 10.1055/s-0041-1735757 ISSN 0379-038X to countries that cannot afford to buy expensive vaccines from other sources. The writings in these journals had cast doubts in the minds of people in India and abroad, about the efficacy of Indian-made vaccines. These vaccines were initially exported to other countries, some of them as gifts from the Government of India. It was promptly halted, not only because of the negative propaganda but also due to the public outcry that Indians are being deprived of the vaccine while it is freely gifted to other countries.

\section{India-Bashing in the Editorials of Journals}

Based on biased critical reports from India, one journal came out with an Editorial on May 8, 2021, titled "India's COVID-19 Emergency," giving a very poor portrayal of India. ${ }^{11}$ Based on incorrectly presented facts, the editorial questioned the sincerity of the Indian leadership and its transparency in implementing the public health policies. In one of its critical remarks, the editorial had stated that only $2 \%$ of people were fully vaccinated in India. As of May 8, 2021, on the day when this editorial was published, 174 million doses of the COVID-19 vaccine were administered, though the vaccination started in India only on January 16, 2021. This may be compared with 263 million vaccinations in the United 
States, where the vaccination started on December $14,2020 .^{12}$ The editorial indicated that there is a vaccine shortage in India, and it was projected as a major failure of the central government. The editorial ignored the fact that India with its gross domestic product (GDP), which is a small fraction of the United States, cannot have a huge stockpile of COVID-19 vaccines. ${ }^{13,14}$ Moreover, India with its estimated population of 1,380 million cannot afford to import all its vaccines. As the vaccination program started in India on January 16, 2021, there were widespread criticisms, especially against Covaxin, the homegrown COVID-19 vaccine, from various quarters including this respected medical journal. ${ }^{5}$ This resulted in a massive rejection of vaccines not only by the general public but also by the health workers. The editorial states that the government abruptly shifted course without discussing the change in policy with states, expanding vaccination to everyone older than 18 years, draining supplies, and creating mass confusion and a market for vaccine doses in which states and hospital systems competed. Can an editorial of an international medical journal of repute make such statements?

We have to agree with the allegation of the journal's editorial that religious and election-related gatherings would have certainly contributed to the second wave of the pandemic. India, with its 28 states and 8 union territories, has a multiracial, multireligious population, with highly religious beliefs rooted in its culture. Election and related gatherings are part of any multiparty democracy. Did the election and election gatherings not take place in the United States during the pandemic? Moreover, studies have now shown that the mutant strains of the virus have contributed toward the second wave of COVID-19. ${ }^{15}$ Another criticism of the editorial was regarding oxygen shortage in some places, during the second wave of COVID-19. The sudden spike in cases resulted in running out of medical oxygen, ventilators, and hospital space, not only in India but even in countries with well-established health care systems..$^{16}$ The editorial is also critical of the hesitancy on the part of the central government to declare a nationwide lockdown during the second wave of the pandemic. It is worth mentioning here that the first nationwide lockdown, declared on the evening of March 24, 2020, by the Government of India, was condemned and criticized in an article published in this very medical journal. ${ }^{4}$ With the second wave coming, the central government of India had given the choice to the state governments, which was again criticized in this journal. The data from the dynamics of epidemics actually had recommended that the state governments should be allowed to decide on this issue based on local data. ${ }^{17}$

Another medical journal published an editorial titled "India, Brazil and the human cost of side-lining science." ${ }^{18}$ In this editorial, both countries have been criticized for not following scientific advice. Brazil's President, Jair Bolsonaro, had been blamed for characterizing COVID-19 as a "little flu" and for refusing to enforce mask-wearing and for limiting contact between people. Quoting their own "World View" article, it says that India's leaders became complacent after daily COVID-19 cases came down after the first wave of the pandemic. This criticism can be best described as an assumption, without evidence. It blames India's leaders for the large gatherings that followed the newly introduced controversial farm laws, election rallies, and religious gatherings. As stated earlier, it is difficult to stop them in a federal multiparty democratic republic. It also quotes an appeal made by some scientists to Prime Minister Narendra Modi, asking for better access to data such as COVID-19 test results and clinical outcomes of patients in hospitals, as well as a large-scale genome-surveillance program to identify new variants. The editorial admits that his criticism is based on a "World View" article published in its journal. The Indian government's principal scientific adviser, Krishnaswamy Vijayraghavan, clarified that the researchers outside the government can always have access to these data. It is gratifying to see that the journal fulfilled its editorial responsibility by publishing this information also in this editorial itself.

A third medical journal published an editorial titled "Political Interference in Public Health Science during Covid-19."19 It states that "Populist leaders like Trump, Bolsonaro, Modi, and Johnson view scientists as their opponents." It quotes an editorial of another journal which stated that "hours before announcing the national lockdown, Prime Minister Narendra Modi told owners and editors from India's largest media organizations that it was important to tackle the spread of pessimism, negativity, and rumor. This pressure to avoid negative news, and to offer reassurance, appears to have been felt by several professional scientific organizations in India." ${ }^{20} \mathrm{Can}$ a request to the media heads to fight against rumor-mongering and spreading of panic amongst the public in the country, be described as a great crime done by a head of state?

\section{Avoid Being a Part of India Shaming}

All the criticisms in the editorials were based on the biased reports that they got from people who have no locus standi in the medical science. But, knowingly or unknowingly, medical professionals also became part of the shaming India campaign. One journal created the COVID-19 commission: India Task Force with 22 members from different parts of India. ${ }^{21}$ The task force, mandated to advise India (assuming that this country is incapable of managing its health care system), came out with several articles that suggested the urgent steps to be taken to contain COVID-19. ${ }^{22-25}$ But, one article was very honest in admitting that several of their recommendations are already part of government advisories and plans. It should be admitted that the portions of the articles, which deal with the situation on the ground during the second pandemic wave, are certainly worth reading.

The establishment of the India Task Force by the journal harkens back to colonial times when British Commissions were created to determine whether Indians were ready for self-rule. Who requested that journal to form the India Task Force? Can they assemble a task force for China or the United States? Will they form a commission to investigate the origins of the severe acute respiratory syndrome coronavirus 2 (SARS-CoV-2) in China, or for that matter, will they lay out 
measures to enforce COVID-19 containment in the United States?

Further the "comment" on June 5, 2021 titled "India's COVID-19 Crisis: A Call for International Action" by 13 authors, mostly by Indians working in North American Universities. ${ }^{26}$ Their condescending concluding remark is quoted here, "We have the knowledge and tools to control SARS-CoV-2 transmission. The current situation in India requires urgent, bold measures and close cooperation between India and the global community to mitigate further damage." This is followed by another "comment" in the same journal, from a set of Indians, published on June 12, 2021, with some recommendations, claimed as a complement to those above-mentioned actions from the "international community." ${ }^{27}$ But they all fail to acknowledge that all their recommendations are already part of government advisories and plans.

India is a vast country with huge responsibility to manage the health sector with a meager $2.4 \%$ GDP devoted to health and related services; it cannot claim its services with the world order. The pandemic has undoubtedly exposed the inadequate medical system in the country but so also the case in so many developed nations. However, with the improvements made in developing the post independence health infrastructure in length and breadth of the country and producing qualified medical and paramedical personnel, the COVID-19 was sufficiently planned and executed scientifically, mostly free of cost, with the support of the government, the nongovernmental organizations, families, and the friends. ${ }^{28}$ This has been appreciated by the patients and the media with the fatality rate still being low. The deficiencies noted during the first and the second wave are being addressed sincerely and hope India will perform better in future to meet such challenges. The efforts are also on to expedite mass vaccination, train the manpower, and equip the intensive care units and pediatric intensive care units for the third wave. The Indian political, medical, and executive systems are mature and competent enough to plan, provide, and perform with the help of its own task force and resources, to take care of its citizens.

\section{Conflict of Interest}

None declared.

\section{References}

1 Breen E. Are medical journals becoming political mouthpieces? BMJ 2020;371:m3878

2 Krishnan V. India's COVID-19 taskforce did not meet in February, March despite surge, say members. The Caravan 22 April 2021. Available at: https://caravanmagazine.in/health/indiacovid-19-taskforce-did-not-meet-february-march-despitesurge-say-members. Accessed August 18, 2021

3 Bhuyan A. Experts criticise India's complacency over COVID-19. Lancet 2021;397(10285):1611-1612

4 Bhuyan A. Indian health care caught up in violence. Lancet 18;395(10219):177-178

5 Bhuyan A. India begins COVID-19 vaccination amid trial allegations. Lancet 2021;397(10271):264
6 Padma TV. India's COVID-vaccine woes-by the numbers. Nature, NEWS 15 APRIL 2021 - icpcovid.com. Available at: https://www.nature.com/articles/d41586-021-00996-y? Accessed August 18, 2021

7 Mallapaty S. India's massive COVID surge puzzles scientists. Nature 2021;592(7856):667-668

8 Mallapaty S. Has COVID peaked? Maybe, but it's too soon to be sure. Nature 2021;591(7851):512-513

9 Vaidyanathan G. Coronavirus variants are spreading in India what scientists know so far. Nature 2021;593(7859):321-322

10 Padma TV. Indian government should heed its scientists on COVID. Nature 2021;593(7857):9

11 The Lancet. India's COVID-19 emergency. Lancet 2021; 397(10286):1683

12 Vaccination update. Available at: https://www.google.com/ search?q=Covid-19+vaccinated+in+india $+\&$ safe=active $\&$ client=firefox-b-d\&biw=1366\&bih=654\&sxsrf=ALeKk03Lz61 xPgubkjkx9c0ZloXzJOGqpg\%3A1620966748413\&ei=XP2dYOzgGMaU4-EP85i4-AU\&oq. Accessed August 18, 2021

13 Country comparison India vs United States. Available at: https://countryeconomy.com/countries/compare/india/usa. Accessed August 18, 2021

14 Kumar VM, Pandi-Perumal SR, Trakht I, Thyagarajan SP. Strategy for COVID-19 vaccination in India: the country with the second highest population and number of cases. NPJ Vaccines $2021 ; 6(1): 60$

15 Covid surge during second wave attributed to double-mutant strain: PGIMER. Available at: https://www.business-standard.com/article/current-affairs/covid-surge-during-secondwave-attributed-to-double-mutant-strain-pgimer-121051600920_1.html. Accessed August 18, 2021

16 Medical Device Shortages During the COVID-19 Public Health Emergency. Available at: https://www.fda.gov/medical-devices/coronavirus-covid-19-and-medical-devices/medical-device-shortages-during-covid-19-public-health-emergency. Accessed August 18, 2021

17 Seshadri MS, John JT. Why India doesn't need a nationwide lockdown now. Available at: https://www.newindianexpress. com/opinions/2021/may/13/why-india-doesnt-need-a-nationwide-lockdown-now-2301813.html. Accessed August 18, 2021

18 India, Brazil and the human cost of sidelining science. Nature, EDITORIAL, 04 May 2021.Available at: https://www.nature. com/articles/d41586-021-01166-w. Accessed August 18, 2021

19 Gonsalves G, Yamey G. Political interference in public health science during covid-19. BMJ 2020;371:m3878

20 The Lancet. COVID-19 in India: the dangers of false optimism. Lancet 2020;396(10255):867

21 The Lancet COVID-19 Commission. Regional Task Force: India. Available at: https://covid19commission.org/regional-taskforce-india. Accessed August 18, 2021

22 The Lancet COVID-19 Commission India Task Force. Country-wide containment strategies for reducing COVID-19 cases in India. Available at: https://covid19commission.org/regional-task-force-india. Accessed on August 18, 2021

23 The Lancet COVID-19 Commission India Task Force. Checklist for country-wide containment strategies to reduce covid-19 cases in India. Available at: https://static1.squarespace.com/ static/5ef3652ab722df11fcb2ba5d/t/60a3ce9b7e2b69785d33f6e0/1621347995814/India+TF+Checklist+April+2021.pdf. Accessed August 18, 2021

24 The Lancet COVID-19 Commission India Task Force. Reopening Schools After COVID-19 Closures. Available at: https:// static1.squarespace.com/static/5ef3652ab722df11fcb$2 \mathrm{ba} 5 \mathrm{~d} / \mathrm{t} / 60 \mathrm{a} 3 \mathrm{cff} 2 \mathrm{~b} 425 \mathrm{ae} 21 \mathrm{a} 5 \mathrm{~b} 49405 / 1621348340073 /$ India+TF+Reopening+Schools+April+2021.pdf. Accessed August 18,2021 
25 The Lancet COVID-19 Commission India Task Force. Managing India's Second COVID-19 Wave: Urgent Steps. Available at: https://static1.squarespace.com/static/5ef3652ab722df11fcb2ba5d/t/6076f57d3b43fb2db4a7c9c9/1618408831746/ India+TF+Policy+Brief+April+2021.pdf. Accessed August 18, 2021

26 Kuppalli K, Gala P, Cherabuddi K, et al. India's COVID-19 crisis: a call for international action. Lancet 2021;397(10290):2132-2135
27 Aiyar Y, Chandru V, Chatterjee M, et al. India's resurgence of COVID-19: urgent actions needed. Lancet 2021;397(10291): 2232-2234

28 Radhakrishnan N, Gupta DK. India's COVID-19 response: science first. Lancet 2021;397(10293):2464-2465 